\title{
Farmers Consciousness on Economic Impact of COVID-19 on Agriculture and Allied Sector in Kashmir
}

\section{Bilal Ahmad Bhat ${ }^{*}$, Sudhakar Dwivedi ${ }^{2}$, Samira Khan ${ }^{3}$, Naveena Nazim ${ }^{1}$ and Bilkees Nazir ${ }^{4}$}

\author{
${ }^{1}$ Sher-e-Kashmir University of Agricultural Sciences and Technology of Kashmir, Kashmir, JEK, India \\ ${ }^{2}$ Sher-e-Kashmir University of Agricultural Sciences and Technology of Kashmir, Jammu, JEK, India \\ ${ }^{3}$ Dammam Imam Abdul Rehman Bin Faisal University, Kingdom of Saudi Arabia, Dammam \\ ${ }^{4}$ Department of Zoology, University of Kashmir, Hazratbal Srinagar, JEK, India
}

${ }^{*}$ Corresponding author: bhat_bilal@rediffmail.com

Received: $10-09-2020$

Revised: $24-11-2020$

Accepted: 05-12-2020

\section{ABSTRACT}

The COVID-19 epidemic poses a challenge to economy, psychological resilience and social life of people at the global level. In India, around 263 million people are directly or indirectly involved in agriculture and more than half of them are part of agriculture labour who were hardest sufferer during COVID-19. The Indian agriculture sector, along with manufacturing and service sectors also became victim of this pandemic. The restrictions imposed due to COVID-19 disease have significantly impacted the agricultural allied sector. The region of Jammu \& Kashmir is an agrarian region, nearly about $70 \%$ of its population directly or indirectly depends upon agriculture also more than $70 \%$ people lives in rural areas. The main objective of the study was to assess the consciousness of farmers of Kashmir valley towards the economic impact of COVID-19 on agriculture and allied sectors. The farmers' lack of consciousness is likely a contributing factor to food standards not being met in most cases. In this study, a welldesigned structured questionnaire was used to assess farmers' general knowledge about impact of COVID-19 on agriculture and allied sectors. The questionnaire was developed with the help of literature available on the topic on six dimensions such as livestock sector, horticulture sector, food sector, agricultural labourers, media and psychological dimension. The data collected from 400 farmers (Central Kashmir = 100, north Kashmir = 150, South Kashmir $=150$ ) using stratified random sampling technique was analysed, tabulated and interpreted using appropriate statistical tools.

The impact of COVID-19 on food and horticulture/floriculture sector was severe. The marketing of fruit crops was affected due to shut down of different activities and non-availability of agricultural labourers. The labourers were supported financially and logistically with supply of food products by government through various schemes. The electronic media emerged as essential tools to disseminate the information through various social media and digital platforms in current COVID-19 pandemic. In order to restore normalcy in the agriculture sector, government should ramp up the infrastructure and provide financial support to the farmers. Finally, it was suggested that government, KVKs, NGOs, responsible citizens should play their role to overcome economic, social and psychological issues caused by COVID-19 pandemic.

Keywords: COVID-19, food and horticulture, livestock, impact.

How to cite this article: Bhat, B.A., Dwivedi, S., Khan, S., Nazim, N and Nazir, B. (2020). Farmers Consciousness on Economic Impact of COVID-19 on Agriculture and Allied Sector in Kashmir. Agro Economist - An International Journal, 7(2): 123-131. Source of Support: None; Conflict of Interest: None 
Agriculture is one of the most important sectors in human development and is related to food security (Abdelhedi and Zouari, 2018; Lopez-Ridaura et al. 2019). In Indian economy, agriculture significantly contributes in fulfilling the food and nutritional requirements of 1.3 billion, besides providing employment and other benefits (GoI, 2016). Within agriculture sector, livestock supports the livelihood of about 70 percent of the rural poor in India, thereby making animal husbandry an important subsidiary occupation of the farmers (Ali, 2007). Despite having fair growth rate, the condition of agriculture is not very good (Iqbal, 2018). Jammu and Kashmir is contributing 70-75 percent to the total production of Apple in India (National Horticulture Board, Horticulture at a Glance, 2018-19), the fifth largest producer of Apple in the world.

Agriculture is already affected by so many factors, including climate change (Ahmad, Dastgir and Haseen; 2011; Kumar and Gautam, 2014), topographical diversities, distinctive socio-economic features (Barah, 2010; Fatima Kaneez and Hussain Anwar, 2014) that affects the food security (FAO; 2008), economic growth, income distribution and agricultural demand (Schmidhuber and Tubiello; 2007; Fahim et al., 2013).

The impact of COVID-19 on agriculture is complex and varied across diverse segments. The new pandemic caused by a novel corona virus, becomes a global threat (Wang, 2020) first detected in December 2019 around a seafood market in the Chinese city of Wuhan Hubei Province (Nishiura, 2020). It is by far the largest outbreak of a typical pneumonia since the severe acute respiratory syndrome (SARS) outbreak in 2003. It is reported that Global economy is projected to grow by $5.8 \%$ in 2021 as economic activity normalizes, helped by policy support (World Economic Outlook, April, 2020). The pandemic has led to uncertainty and created high transaction costs in the food-supply chains in India (Reardon et al. 2020). There is a fall in both supply and demand for food which impact agriculture substantially, so there is possibility of food-insecurity across the world (Barua et al. 2020; Brewin, 2020). The COVID-19 pandemic is affecting agriculture in two significant aspects: the supply and demand for food (FAO, 2020b). COVID-19 has also affected the migrant workers worldwide (FAO, 2020a).
The supply-chain of major agricultural products in Jammu and Kashmir is drastically hit due to disruption by COVID-19 pandemic (Hassan, The Wire, 2020). Therefore, the present study was planned to assess the farmers' perception on economic impact of COVID-19 on agriculture and allied sectors in Kashmir valley.

\section{MATERIALS AND METHODS}

In this study, a well-designed structured questionnaire based on literature was used to assess farmers' general knowledge about the food safety aspects and animal health standards in Kashmir valley of J\&K. The participants under study were explained the purpose of this study in local language and were given assurance about the confidentiality. The responses were collected in categorical variable viz., Agree or Disagree, against each statement related to different sectors such as livestock, horticulture, food, labourers, media and psychology. In order to compare the opinion of rural and urban people, 5 -point likert scale was used. Based on the fivepoint scale (5: strongly agree; 4: agree; 3: neutral; 2: disagree; 1: strongly disagree), a mean score of 3.0 was used as the benchmark of the study. The data collected from 400 farmers (100 from central Kashmir, 150 from South Kashmir and 150 from North Kashmir) via offline and online mode using stratified random sampling technique was tabulated, analysed and interpreted using standard statistical tools. The sample size for our survey was calculated using the formula (Cochran, 1977)

$$
n=\frac{Z_{\alpha}^{2} P(1-P)}{d^{2}}
$$

We chose here $p=0.5, Z_{\alpha}=1.96$ and $d=0.05$. That gives the sample size $n \sim 384$ and we take $n=400$. The data collected from our online survey was tabulated, analyzed and interpreted statistically. Statistical software SPSS (version 20) was used for analysis of data.

\section{Research Hypothesis}

Hypothesis 1: There is no significant difference in awareness between rural and urban farmers of Kashmir valley. 
In order to test the hypothesis 1, we use MannWhitney $U$ test (with usual notations) given by the formula:

$$
W=N_{1} N_{2}+\frac{N_{x}\left(N_{x}+1\right)}{2}-T_{x}
$$

where $N_{1}$ is the number of subjects in group $1 ; N_{2}$ is the number of subjects in group 2. $T_{x}$ is the larger of the two rank totals and $N_{x}$ is the number of subjects in this group.

Hypothesis 2: There is no significant difference among the farmers' perception in Central, North and South Kashmir.

In order to test Hypothesis 2, we use Kruskal-Wallis test. The Kruskal-Wallis (1952) test statistics for $k$ samples, each of size $n_{i}$ (with usual notations) is given by,

$$
H=\frac{12}{n(n+1)} \sum_{i} \frac{R_{i}^{2}}{n_{i}}-3(n+1)
$$

where $n$ is the total number (all $n_{i}$ ) and $R_{i}$ is the sum of the ranks (from all samples pooled) for the $i^{\text {th }}$ sample.

\section{RESULTS AND DISCUSSION}

\section{Farmers' assessment of COVID-19 impact on livestock sector}

The response to statement 1, i.e. 'Do you feel that farmers are facing problem in selling of milk in your area', the majority of the respondents (53.25\%) agreed (Table 1). The results were in consonance with findings of Bhandari et al. (2020) and Palsaniya et al. (2020) who reported that the livestock farmers found it difficult to sell the milk and other meat products in current COVID-19 spread. The majority of the respondents $(73.25 \%)$ were disagreeing with the statement 2, i.e., 'Do you think that the prices of milk have fallen down in the villages'. In response to statement 3, i.e., Do you feel that there is an interrupted supply of feed and concentrate for animals, majority of the respondents (81.0\%) agreed. The study conducted by FAO (2020) on impact of COVID-19 on livestock sector and found similar results as of our study. In response to statement 4, i.e., Do you think that Agricultural Scientists and Veterinarians are serving uninterruptedly for the farmers, majority of the respondents (68.25\%) agreed and in response to statement 5, i.e., Do you feel that Government has allowed farmers to sell their products with curfew passes is a good initiative, majority of the respondents $(88.0 \%)$ agreed. In response to statement 6, i.e., Do you think that Agricultural Scientists and Veterinarians are serving uninterruptedly for the farmers, majority of the respondents $(78.5 \%)$ agreed.

Table 1: Farmers' assessment of COVID-19 impact on

\begin{tabular}{|c|c|c|}
\hline \multirow[t]{2}{*}{ Statements } & \multicolumn{2}{|c|}{ Response } \\
\hline & Agree & Disagree \\
\hline $\begin{array}{l}\text { Do you feel that farmers are } \\
\text { facing problem in selling of } \\
\text { milk in your area? }\end{array}$ & $\begin{array}{l}213 \\
(53.25)\end{array}$ & $\begin{array}{l}187 \\
(46.75)\end{array}$ \\
\hline $\begin{array}{l}\text { Do you think that the prices of } \\
\text { milk have fallen down in the } \\
\text { villages? }\end{array}$ & $\begin{array}{l}107 \\
(26.75)\end{array}$ & $\begin{array}{l}293 \\
(73.25)\end{array}$ \\
\hline $\begin{array}{l}\text { Do you feel that there is an } \\
\text { interrupted supply of feed and } \\
\text { concentrate for animals? }\end{array}$ & $\begin{array}{l}234 \\
(81.0)\end{array}$ & $\begin{array}{l}166 \\
(19.0)\end{array}$ \\
\hline $\begin{array}{l}\text { Do you think that Agricultural } \\
\text { Scientists and Veterinarians are } \\
\text { serving uninterruptedly for the } \\
\text { farmers? }\end{array}$ & $\begin{array}{l}273 \\
(68.25)\end{array}$ & $\begin{array}{l}127 \\
(31.75)\end{array}$ \\
\hline $\begin{array}{l}\text { Do you feel that Government } \\
\text { has allowed farmers to sell their } \\
\text { products with curfew passes is } \\
\text { a good initiative? }\end{array}$ & $\begin{array}{l}352 \\
(88.0)\end{array}$ & $48(12.0)$ \\
\hline $\begin{array}{l}\text { Do you feel that appropriate } \\
\text { advisories provided by KVK } \\
\text { experts through different social } \\
\text { media are effective? }\end{array}$ & $\begin{array}{l}314 \\
(78.5)\end{array}$ & $86(21.5)$ \\
\hline
\end{tabular}
livestock sector $(n=400)$

Note: Figures in parentheses indicate percentage.

\section{Farmers' assessment of COVID-19 impact on horticulture sector}

In response to statement 1 , i.e., Do you feel that the harvesting of major fruit crops has been affected in our area, majority of the respondents (59.25\%) agreed (Table 2). In response to statement 2, i.e., Do you think that due to restricted opening of shops the supply of critical inputs can be assured for farmers, majority of the respondents $(61.50 \%)$ disagree. In response to statement 3, i.e., Do you feel that the 
sale and transportation of ornamental flowers and seedling/saplings from nurseries have been severely affected, majority of the respondents $(84.0 \%)$ agreed. In response to statement 4 , i.e., Do you feel that as an alternative mechanism for marketing such as door to door supply has empowered group of farmers, majority of the respondents $(54.25 \%)$ agreed and in response to statement 5, i.e., Are you satisfied with the joint efforts of KVKs with FPOs/FPCs/SHGs to solve the horticulture-related problems to a greater extent in the area, majority of the respondents $(55.75 \%)$ agreed, in response to statement 6, i.e., Do you feel that relaxation is given by Govt. has helped the farmers, traders, vendors, etc. in meeting the demand and supply of horticultural commodities up to a certain extent, majority of the respondents $(94.75 \%)$ agreed. In a study conducted by Mukherjee et al. (2018), it was reported that government institutions, Self Help Groups, Farmers Interest Groups, and Farmers' Cooperatives etc. contribute for the welfare of farmers.

Table 2: Farmers' assessment of COVID-19 impact on horticulture sector

\begin{tabular}{|c|c|c|}
\hline \multirow[t]{2}{*}{ Statements } & \multicolumn{2}{|c|}{ Response } \\
\hline & Agree & Disagree \\
\hline $\begin{array}{l}\text { Do you feel that the harvesting } \\
\text { of major fruit crops has been } \\
\text { affected in our area? }\end{array}$ & $\begin{array}{l}237 \\
(59.25)\end{array}$ & $\begin{array}{l}163 \\
(40.75)\end{array}$ \\
\hline $\begin{array}{l}\text { Do you think that due to } \\
\text { restricted opening of shops the } \\
\text { supply of critical inputs can be } \\
\text { assured for farmers? }\end{array}$ & $\begin{array}{l}246 \\
(61.50)\end{array}$ & $\begin{array}{l}154 \\
(38.50)\end{array}$ \\
\hline $\begin{array}{l}\text { Do you feel that the sale and } \\
\text { transportation of ornamental } \\
\text { flowers and seedling/saplings } \\
\text { from nurseries have been } \\
\text { severely affected? }\end{array}$ & $\begin{array}{l}336 \\
(84.00)\end{array}$ & $\begin{array}{l}64 \\
(16.00)\end{array}$ \\
\hline $\begin{array}{l}\text { Do you feel that as an } \\
\text { alternative mechanism for } \\
\text { marketing such as door to door } \\
\text { supply has empowered group } \\
\text { of farmers? }\end{array}$ & $\begin{array}{l}217 \\
(54.25)\end{array}$ & $\begin{array}{l}183 \\
(45.75)\end{array}$ \\
\hline $\begin{array}{l}\text { Are you satisfied with the joint } \\
\text { efforts of KVKs with FPOs/ } \\
\text { FPCs/SHGs to solve the } \\
\text { horticulture-related problems } \\
\text { to a greater extent in the area? }\end{array}$ & $\begin{array}{l}223 \\
(55.75)\end{array}$ & $\begin{array}{l}177 \\
(44.25)\end{array}$ \\
\hline
\end{tabular}

Do you feel that relaxation $\quad 379 \quad 21$ is given by Govt. has helped the farmers, traders, vendors, (94.75) (5.25) etc. in meeting the demand and supply of horticultural commodities up to a certain extent?

Note: Figures in parentheses indicate percentage.

\section{Farmers' assessment of COVID-19 impact on food crops}

In response to statement 1, i.e., Do you feel that harvesting of major food crops could be completed almost at proper time, majority of the respondents $(77.25 \%)$ agreed (Table 3$)$.

Table 3: Farmers' assessment of COVID-19 impact on food crops

\begin{tabular}{|c|c|c|}
\hline \multirow{2}{*}{ Statements } & \multicolumn{2}{|c|}{ Response } \\
\hline & Agree & Disagree \\
\hline $\begin{array}{l}\text { Do you feel that harvesting } \\
\text { of major food crops could be } \\
\text { completed almost at proper } \\
\text { time? }\end{array}$ & $\begin{array}{l}309 \\
(77.25)\end{array}$ & $91(22.75)$ \\
\hline $\begin{array}{l}\text { Do you feel that Government } \\
\text { initiative of procurement } \\
\text { centers for different food } \\
\text { grains and horticultural } \\
\text { produce will help the } \\
\text { farmers? }\end{array}$ & $\begin{array}{l}316 \\
(79.00)\end{array}$ & $84(21.00)$ \\
\hline $\begin{array}{l}\text { Do you feel that regular farm } \\
\text { labour unavailability will } \\
\text { increase labour cost and cost } \\
\text { of cultivation of crops? }\end{array}$ & $\begin{array}{l}329 \\
(82.25)\end{array}$ & 71 (17.75) \\
\hline $\begin{array}{l}\text { Do you feel that Custom } \\
\text { Hiring Centers has played } \\
\text { crucial role in supplying } \\
\text { big farm machineries and } \\
\text { other equipments for farm } \\
\text { operations? }\end{array}$ & $\begin{array}{l}231 \\
(57.75)\end{array}$ & $69(42.25)$ \\
\hline $\begin{array}{l}\text { Do you feel that State and } \\
\text { technology driven advisories } \\
\text { issued by ICAR/ SAUs/ } \\
\text { KVKs has helped the } \\
\text { farmers to tackle the related } \\
\text { problems? }\end{array}$ & $\begin{array}{l}291 \\
(72.75)\end{array}$ & $109(27.25)$ \\
\hline
\end{tabular}




\begin{tabular}{lll}
$\begin{array}{l}\text { Are you satisfied with } \\
\text { initiatives taken by Govt. to } \\
\text { overcome issues of farmers }\end{array}$ & 262 & 138 (34.50) \\
for food crops? & & \\
\hline
\end{tabular}

Note: Figures in parentheses indicate percentage.

In response to statement 2, i.e., Do you feel that Government initiative of procurement centers for different food grains and horticultural produce will help the farmers, majority of the respondents $(79.00 \%)$ agree. In response to statement 3, i.e., Do you feel that regular farm labour unavailability will increase labour cost and cost of cultivation of crops, majority of the respondents $(82.25 \%)$ agreed. In response to statement 4 , i.e., Do you feel that as an alternative mechanism for marketing such as door to door supply has empowered group of farmers, majority of the respondents $(57.25 \%)$ agreed. The results of our study are in agreement with the earlier study conducted by Chahal et al. (2014) who reported that Custom Hiring Centres have huge potential in supplying farm machineries at cheaper rate to farmers. Iin response to statement 5 , i.e., Do you feel that State and technology driven advisories issued by ICAR/ SAUs/KVKs has helped the farmers to tackle the related problems, majority of the respondents $(72.75 \%)$ agreed, in response to statement 6, i.e., Are you satisfied with initiatives taken by Govt. to overcome issues of farmers for food crops, majority of the respondents $(65.50 \%)$ agreed.

\section{Farmers assessment of COVID-19 impact on labourers in agriculture and allied sector}

In response to statement 1 , i.e., Do you feel that daily landless wage workers affected most due to coronavirus infection, majority of the respondents (91.75\%) agreed Table 4). In response to statement 2, i.e., Do you feel that Procurement operations have been affected due to labour shortage for loading, unloading of produce, majority of the respondents $(71.00 \%)$ agree. In response to statement 3, i.e., Do you feel that despite of work, some workers want to stay home and waiting for Government welfare schemes, majority of the respondents (56.50\%) agreed.

In response to statement 4 , i.e., Do you think that migratory workers will start his/her enterprise in their area according to their skill/expertise, majority of the respondents (51.25\%) disagreed and in response to statement 5 , i.e., Do you feel that financial assurance through MGNREGA, PM Jan Dhan Yojna and Kisan Samman Nidhi (KISAN) Yojna has helped the farmers, majority of the respondents $(61.75 \%)$ agreed. Recently (Hindustan Times, 2020), it has been reported that

Table 4: Farmers assessment of COVID-19 impact on labourers in agriculture and allied sector

\begin{tabular}{|c|c|c|}
\hline \multirow[b]{2}{*}{ Statements } & \multicolumn{2}{|c|}{ Response } \\
\hline & $\begin{array}{l}\text { Agree } \\
(\%)\end{array}$ & $\begin{array}{l}\text { Disagree } \\
(\%)\end{array}$ \\
\hline $\begin{array}{l}\text { Do you feel that daily } \\
\text { landless wage workers } \\
\text { affected most due to } \\
\text { coronavirus infection? }\end{array}$ & $\begin{array}{l}367 \\
(91.75)\end{array}$ & 33 (8.25) \\
\hline $\begin{array}{l}\text { Do you feel that Procurement } \\
\text { operations have been affected } \\
\text { due to labour shortage } \\
\text { for loading, unloading of } \\
\text { produce? }\end{array}$ & $\begin{array}{l}284 \\
(71.00)\end{array}$ & $116(29.00)$ \\
\hline $\begin{array}{l}\text { Do you feel that despite of } \\
\text { work, some workers want } \\
\text { to stay home and waiting } \\
\text { for Government welfare } \\
\text { schemes? }\end{array}$ & $\begin{array}{l}226 \\
(56.50)\end{array}$ & $174(43.50)$ \\
\hline $\begin{array}{l}\text { Do you think that migratory } \\
\text { workers will start his/ } \\
\text { her enterprise in their area } \\
\text { according to their skill/ } \\
\text { expertise? }\end{array}$ & $\begin{array}{l}195 \\
(48.50)\end{array}$ & $205(51.25)$ \\
\hline $\begin{array}{l}\text { Do you feel that financial } \\
\text { assurance through } \\
\text { MGNREGA, PM Jan Dhan } \\
\text { Yojna and Kisan Samman } \\
\text { Nidhi (KISAN) Yojna has } \\
\text { helped the farmers? }\end{array}$ & $\begin{array}{l}247 \\
(61.75)\end{array}$ & $153(38.25)$ \\
\hline $\begin{array}{l}\text { Do you feel that labourers } \\
\text { can work in the field on the } \\
\text { slogan of Do Gajki Doori } \\
\text { (distancing by } 2 \text { feet) and by } \\
\text { practicing hygiene practices? }\end{array}$ & $\begin{array}{l}261 \\
(65.25)\end{array}$ & $139(34.75)$ \\
\hline
\end{tabular}

Note: Figures in parentheses indicate percentage.

Under the PM-KISAN Yojana 6.93 crore farmers were benefited over the Covid-19 crisis. The government transfers ₹ 2,000 cash directly to the farmers' bank accounts through direct benefit transfer or DBT 
under the scheme and ₹ 13,855 crore have gone towards payment of first instalment. Recently, Lieutenant Governor of Jammu and Kashmir Manoj Sinha in an event held simultaneously with Prime Minister Narendra Modi disbursing ₹ 18,000 crore to nine crore farmers across India under the PMKISAN scheme, was addressing farmers during a programme held at Kisan Kendra in Jammu in which the latest instalment under the PM-KISAN scheme was disbursed to beneficiaries. The Lt Governor of J\&K Sinha observed that the farmers of Jammu and Kashmir have been provided with financial assistance worth ₹ 1,132 crore under the scheme so far. The Lt Governor said in his speech that the administration's priorities are promotion of agriculture, horticulture, dairy and poultry sectors. It has been also reported (Hindustan Times, 2020) that under Jan Dhan scheme, 19.86 crore women account holders received ₹ 500 each in their account with the total disbursement of ₹ 9,930 crore. In response to statement 6, i.e., Do you feel that labourers can work in the field on the slogan of Do Gajki Doori (distancing by 2 feet) and by practicing hygiene practices, majority of the respondents $(65.25 \%)$ agreed.

\section{Farmers assessment of social media in terms of information dissemination related to COVID-19}

In response to statement 1 , i.e., I felt there is a need for online delivery of seasonal and crop-specific farm inputs, majority of the respondents (77.25\%) agreed (Table 5). In response to statement 2, i.e., I think that Agro-advisory given by KVKs is found reliable and action oriented for farmers, majority of the respondents $(93.00 \%)$ agree. In response to statement 3, i.e., I think that Social media and digital platforms are ways to help farmers in situation like COVID-19 pandemic, majority of the respondents $(82.00 \%)$ agreed. In response to statement 4 , i.e., Apps like Zoom were found useful for video conferencing among farmers groups and others experts to resolve the farm related problems/issues, majority of the respondents $(58.50 \%)$ agreed and in response to statement 5, i.e., I always believe in authentic information disseminated by Govt. website (Ministry of Health and Family Welfare, WHO, ICMR/ Arogya SetuApp)/ Govt portals/websites, majority of the respondents $(94.00 \%)$ agreed, in response to statement 6, i.e., I think that Kisan Call Centres has

helped farmers responding their queries, majority of the respondents $(71.50 \%)$ agreed.

Table 5: Farmers assessment of social media in terms of information dissemination related to COVID-19

\begin{tabular}{|c|c|c|}
\hline \multirow[b]{2}{*}{ Statements } & \multicolumn{2}{|c|}{ Response } \\
\hline & Agree (\%) & $\begin{array}{l}\text { Disagree } \\
(\%)\end{array}$ \\
\hline $\begin{array}{l}\text { I felt there is a need for online } \\
\text { delivery of seasonal and crop- } \\
\text { specific farm inputs }\end{array}$ & $341(85.25)$ & 59 (14.75) \\
\hline $\begin{array}{l}\text { I think that Agro-advisory given } \\
\text { by KVKs is found reliable and } \\
\text { action oriented for farmers }\end{array}$ & $372(93.00)$ & $28(7.00)$ \\
\hline $\begin{array}{l}\text { I think that Social media and } \\
\text { digital platforms are ways to } \\
\text { help farmers in situation like } \\
\text { COVID-19 pandemic }\end{array}$ & $328(82.00)$ & $72(18.00)$ \\
\hline $\begin{array}{l}\text { Apps like Zoom were found } \\
\text { useful for video conferencing } \\
\text { among farmers groups and } \\
\text { others experts to resolve the farm } \\
\text { related problems/issues }\end{array}$ & $234(58.50)$ & $\begin{array}{l}166 \\
(41.50)\end{array}$ \\
\hline $\begin{array}{l}\text { I always believe in authentic } \\
\text { information disseminated by } \\
\text { Govt. website (Ministry of Health } \\
\text { and Family Welfare, WHO, } \\
\text { ICMR/Arogya SetuApp)/ Govt } \\
\text { portals/websites }\end{array}$ & $376(94.00)$ & $24(6.00)$ \\
\hline $\begin{array}{l}\text { I think that Kisan Call Centres } \\
\text { has helped farmers responding } \\
\text { their queries }\end{array}$ & 286 (71.50) & $\begin{array}{l}114 \\
(28.50)\end{array}$ \\
\hline
\end{tabular}

Note: Figures in parentheses indicate percentage.

\section{Farmers' assessment towards psychological effect of COVID-19}

In response to statement 1 , i.e., I support the needy persons around me during distress situation, majority of the respondents $(92.75 \%)$ agreed (Table 6). In response to statement 2 , i.e., I have a mental fear of losing savings and even basic services during COVID-19, majority of the respondents $(71.50 \%)$ disagree. In response to statement 3, i.e., Feeling of frustration when others are not following the precautionary measures for COVID-19, majority of the respondents (72.25\%) agreed. Varshney et al. (2020) who reported in their study that almost one-third respondents had a significant psychological impact 
of COVID-19 during the initial stages of COVID-19 pandemic in India. In response to statement 4, i.e., Lifestyle of people could be changed after COVID-19 pandemic in public and private places, majority of the respondents $(82.00 \%)$ agreed and in response to statement 5, i.e., I think people will understand the importance of sanitation (Swachch Bharat Abhiyan) and people will practice more hygiene and table etiquettes, majority of the respondents $(79.75 \%)$ agreed, in response to statement 6, i.e., I think Arogya Setu App has helped people regarding staying away from infection, symptoms, regular check and other recommendations regarding protection from COVID-19 and for getting vehicle passes, majority of the respondents $(56.75 \%)$ disagreed.

Table 6: Farmers' assessment towards psychological effect of COVID-19

\begin{tabular}{lll}
\hline & \multicolumn{2}{c}{ Response } \\
\cline { 2 - 3 } Statements & $\begin{array}{l}\text { Agree } \\
(\%)\end{array}$ & $\begin{array}{l}\text { Disagree } \\
\text { (\%) }\end{array}$ \\
\hline $\begin{array}{l}\text { I support the needy persons } \\
\text { around me during distress }\end{array}$ & 371 & $29(7.25)$ \\
$\begin{array}{l}\text { situation } \\
\text { I have a mental fear of losing }\end{array}$ & 114 & $286(71.5)$ \\
$\begin{array}{l}\text { savings and even basic services } \\
\text { during COVID-19 }\end{array}$ & $(28.5)$ & \\
$\begin{array}{l}\text { Feeling of frustration when } \\
\text { others are not following the }\end{array}$ & 289 & $111(27.75)$ \\
precautionary measures for & $(72.25)$ & \\
$\begin{array}{l}\text { COVID-19 } \\
\text { Lifestyle of people could be } \\
\text { changed after COVID-19 } \\
\text { pandemic in public and private } \\
\text { places }\end{array}$ & 328 & $72(18.00)$ \\
$\begin{array}{l}\text { I think people will understand } \\
\text { the importance of sanitation }\end{array}$ & 319 & $81(20.25)$ \\
$\begin{array}{l}\text { (Swachch Bharat Abhiyan) and } \\
\text { people will practice more hygiene } \\
\text { and table etiquettes }\end{array}$ & & \\
$\begin{array}{l}\text { I think Arogya Setu App } \\
\text { has helped people regarding } \\
\text { staying away from infection, } \\
\text { symptoms, regular check and } \\
\text { other recommendations regarding } \\
\text { protection from COVID-19 and } \\
\text { for getting vehicle passes }\end{array}$ & & \\
\hline
\end{tabular}

Note: Figures in parentheses indicate percentage.

\section{Comparison of opinions regarding COVID-19 impact}

Statistically, there was a significant difference $(p<0.01)$ between rural and urban opinions regarding COVID-19 impact on agriculture and allied sectors (Table 7). Also, there was a significant difference $(p<0.01)$ between opinions of respondents living in different zones of Kashmir $(\mathrm{p}<0.01)$. The respondents from South Kashmir were feeling more problems compared to other zones of Kashmir (Table 8).

Table 7: Comparison of rural and urban opinions regarding COVID-19 impact on agriculture and allied sectors

\begin{tabular}{llll}
\hline Statement & Region & Mean \pm S.E. $W$ & P-value \\
\hline COVID-19 & Rural & $3.426923 \pm$ & $45715.0<0.01$ \\
impacted & $(\mathrm{n}=260)$ & 0.067 & \\
Economy based & Urban & $4.107143 \pm$ & \\
$\begin{array}{l}\text { on Agriculutre } \\
\text { and Allied }\end{array}$ & $(\mathrm{n}=140)$ & 0.0697 & \\
\hline
\end{tabular}

Agree $=5$, Strongly Agree $=4$, No Idea $=3$, Disagree $=2$ and Strongly Disagree $=1$.

The statement related to impact of COVID-19 on economic and social life of people, the respondents in majority agreed . Statistically, there was a significant difference in the opinion

Table 8: Comparison of opinions regarding COVID-19 impact across different areas

\begin{tabular}{lllll}
\hline Statement & Region & $\begin{array}{l}\text { Mean } \pm \\
\text { S.E. }\end{array}$ & H & P-value \\
\hline COVID-19 & South Kashmir & $4.040 \pm$ & 18.90 & $<0.01$ \\
impacted & $(\mathrm{n}=150)$ & 0.085 & & \\
economy and & Central Kashmir & $3.56 \pm$ & & \\
social life of & $(\mathrm{n}=100)$ & 0.0884 & & \\
people & North Kashmir & $3.420 \pm$ & & \\
& $(\mathrm{n}=150)$ & 0.0897 & & \\
\hline
\end{tabular}

Strongly Agree $=5$, Agree $=4$, No Idea $=3$, Disagree $=2$ and Strongly Disagree $=1$.

\section{CONCLUSION}

COVID-19 pandemic is causing widespread concern, depression and anxiety among the people. It has produced enormous effect on agriculture and 
allied sectors in Jammu and Kashmir and India. The study revealed that the farmers in dairy sector faced problems such as non-availability of feed and fodder, unstable demand and price of milk and other products, fall in poultry meat, fisheries and goatry sector. The people living in urban areas were feeling more impact on their economy due to COVID-19 lockdown. Kashmiri farmers are mainly dependent on migrant labouers and COVID-19 pandemic cause shortage of manpower and loss of agricultural produce. Farmers need to adopt the new norm of life with COVID-19, follow government marketing advisory for farm and farm produce, WHO guidelines and health ministry advisory. It is concluded that Government and NGO's should support farming community and aware them about issues related to deadly disease COVID-19.

\section{ACKNOWLEDGEMENTS}

The authors would like to thank all the farmers who participated in this study especially to their educated family members who helped in communication. The authors further acknowledge the support of scientists from KVKs.

\section{REFERENCES}

Abdelhedi, I.T. and Zouari, S.Z. 2018. Agriculture and Food Security in North Africa: a Theoretical and Empirical Approach. Journal of the Knowledge Economy, 1-18.

Ahmad, J.A., Dastgir and Haseen, S. 2011. Impact of climate change on agriculture and food security in India. International Journal of Agricultural Environmental and Biotechnology, 4(2): 129-137.

Ali, J. 2007. Livestock sector development and implications for rural poverty alleviation in India. Research for Rural Development, 19(2).

Barro, R., Ursua, J., and Weng, J. 2020. Coronavirus Meets the Great Influenza Pandemic. VoxEU. org, 20.

Bhandari, G. and Ravishankar, K.M. 2020. Implications of COVID-19 for Indian dairy sector. Food and Scientific Reports, May, 1: 43-46.

Boissay, F. and Rungcharoenkitkul, P. 2020. Macroeconomic effects of Covid-19: an early review. Bank for International Settlements, 7 .

Brewin, D. 2020. The impact of COVID-19 on the grains and oilseeds sector. Canadian Journal of Agricultural Economics/Revue canadienne d'agroeconomie.

Chahal, S.S., Kataria, P. Abbott., S. and Gill, B.S. 2014. Role of cooperatives in institutionalization of custom hiring services in Punjab. Agricultural Economics Research Review, 27(Conf): 103-110.
Chakraborty, I. and Maity, P. 2020. COVID-19 outbreak: Migration, effects on society, global environment and prevention. Science of the Total Environment, 138882.

Cochran, W.G. 1977. Sampling Techniques, $3^{\text {rd }}$ edition. New York: John Wiley \& Sons.

Fahim, M.A., Hassanein, M.K., Abolmaty, S.M., Khalil, A.A. and Hadid, A.F.A. 2013. Climate change adaptation needs for food security in Egypt. Natural Sciences, 11(12): 68-74.

FAO. 2020a. Migrant workers and the COVID-19 pandemic. Rome.

FAO. 2020b. Mitigating the impacts of COVID-19 on the livestock sector. Rome. https://doi.org/10.4060/ ca8799en.

Government of India. 2016. State of Indian agriculture, 201516, retrieved from http://eands.dacnet.nic.in/ PDF/ State_of_Indian_Agriculture, 2015-16.pdf.

Government of India. 2019. Ministry of Statistics, Planning and Implementation, National Sample Survey Office. "Horticulture at a Glance, 2018".

Hindustan Times. 2020. PM-KISAN, Jan Dhan, Ujjawala: Govt lends Rs 30,000 crore helping hand in Covid- 19 crisis (12 April), assessed at https:/ / www.hindustantimes.com/ india-news/pm-kisan-jan-dhan-ujjawala-how-govtishelping-in-covid-19-crisis/story-gtNSv87n72HPKO VYEIkXXL.html.

Iqbal, A.B. 2018. Indian agriculture: Issues and Challenges. Journal of Food Science and Toxicology, 2(1):4.

Kaneez, F. and Hussain, A. 2012. Problems and prospects of hill farming. Research Journal of Agricultural Sciences, 3(2): 578-580.

Kumar, R. and Gautam, H.R. 2014. Climate Change and its Impact on Agricultural Productivity in India. Journal of Climatology \& Weather Forecasting, 2: 109.

Nishiura, H., Jung, S., Linton, N.M., Kinoshita, R., Yang, Y., Hayashi, K., Kobayashi, T., Yuan, B. and Akhmetzhanov, A.R. 2020. The Extent of Transmission of Novel Coronavirus in Wuhan, China. Journal of Clinical Medicine, 9: 330.

Palsaniya, D.R. and Maity, A. 2020. Fodder and livestock sector in India during COVID-19 lock down: possible impacts and mitigation strategies. Food and Scientific Reports, 1: 34-35.

Reardon, T., Bellemare, F.M. and Zilberman, D. 2020. How COVID-19 may disrupt food supply chains in developing countries. International Food Policy Research Institute. https://www. ifpri. org/blog/how-covid.

Schmidhuber, J. and Tubiello, F.N. 2007. Global food security under climate change. Proceedings of the National Academy of Sciences of the United States of America, 104(50): 581-596.

Varshney, M., Parel, J.T., Raizada, N. and Sarin, S.K. 2020. Initial psychological impact of COVID-19 and its correlates in Indian Community: an online (FEELCOVID) survey. Plos One, 15(5): e0233874. 
Wang, C. 2020. A novel coronavirus outbreak of global health concern. Lancet, 395: 470-473.

Wani, H. 2020. Kashmir: COVID-19 Lockdown Adds to Woes of Apple Growers and Trader, The Wire (April 17), retrieved from, "https://thewire.in/agriculture/ kashmir-covid-19-lockdown-apple-traders".
WHO. 2020. Director-General's opening remarks at the media briefing on COVID-19 $-11^{\text {th }}$ March. World Health Organization. www.who.org.

World Economic Outlook Reports. 2020. World Economic Outlook, April 2020: The Great Lockdown. 
